SITES: NEW SERIES · VOL 9 NO $2 \cdot 2012$

DoI: http://dx.doi.org/10.11157/sites-volgiss2id212

- ARTICLE -

\author{
D'ARCY'S VIEW FROM THE HILL: \\ 'WEAK THOUGHT' ON PAKEHA AS PARTICULAR, REgIONAL 'BUGGERS'...'
}

Mike Grimshaw

\begin{abstract}
This paper argues for the cultural development of 'Pakeha' as a particular mid 2oth century regional, secular, modernist identity and belief that developed in the South Island between the 1920s and the late 1950s. Beginning with the influence of D'arcy Cresswell who, in 1923, claimed a new type of Pakeha indigeneity in a supposedly 'terra nullis', it argues Pakeha arises out of a distinctly modernist identity: secular, urban, exilic and literary. Pakeha, as a condition of modernity, arises in the South Island because it is a claim of a type of indigeneity situated against the North Island. It arises out of the tensions of a providential land, a desert, a wilderness and a waste land where a new society has to be built from scratch. The challenge of 'Pakeha' to New Zealanders is the challenge of a specific identity that may indeed challenge nationalist cultural essentialisms. Not all European New Zealanders are necessarily Pakeha, nor will they necessarily wish to be. For Pakeha is first and foremost a type of modernist belief. ${ }^{2}$
\end{abstract}

\title{
THE CHALLENGE OF IDENTITY
}

One does not come to write on Pakeha identity out of a void. Born on the North Shore in 1967, I have lived almost all my life in the South Island. I grew up in Queenstown and Geraldine, studied at Otago University for over a decade and now teach at Canterbury University. Looking back, the spur to my engagement with issues of identity and location was formed by the works of New Zealand poets and artists, and, in particular, the challenges laid down by Denis Glover and Basil Dowling. From Glover came the challenge and hope of 'Home Thoughts' (orig. 1935) concluding stanza:

I do not dream of Sussex downs

Or quaint old England's quaint old towns: 
I think of what will yet be seen

In Johnsonville and Geraldine.

(Glover, 1945:14)

I still remember the effect of reading those words as a teenager, living in Geraldine. At that time I wished (in the clichéd manner of so many young inhabitants of small towns) to be elsewhere, anywhere but in this pretty, stolid, small, small town; the type of place an old transplanted Englishman, father of my brother's friend, would refer to dismissively as 'a mental mudflat.' It was a time (early 1980s) and I was of an age (15 or 16) when 'life' (whatever that was) was located elsewhere; perhaps most vividly in either the 'Geordies on a laddish rampage in Germany' of Auf Wiedersehen Pet, or conversely (perversely), the elegant Anglo-Catholic decay of Brideshead Revisited; both playing on Television. Aware that both grandfathers had emigrated from Bolton and Edinburgh to Auckland in the 1920s, I was feeling most strongly that sense of dis-location perhaps most keenly felt by the second generation of settlers.

Then I stumbled across Glover's poem. He was talking about where I was: my location, my dis-location, had become 'literazied', 'enculturated', deemed worthy of notice, 'located' even if in a sardonic way. Perhaps a late developer, I had been (I felt) in that situation which Morris Shadbolt later described of those born in New Zealand in the 1930s: 'My generation inherited a land no longer a colony and not yet a nation. We were no longer Europeans and not yet New Zealanders' (Shadbolt, 1993:174).

Glover helped me along those first tentative steps of Pakeha identity. Though I continued to read predominantly British and American literature, I did so now through consciously New Zealand eyes. I saw and read my landscape as it was, not what I wished it to be; I discovered New Zealand art and artists such as Colin McCahon, Toss Woolaston, Bill Sutton, Dean Buchanan, Rita Angus, Nigel Brown, who articulated their 'sense of place'.

Such questions have been a recurrent strand in New Zealand notions of identity, as the poet Basil Dowling wrote of the Canterbury Plains:

....This is my holy land

Of childhood. Trying to comprehend

And learn it like the features of a friend,...

(Dowling, 1949:10-11).

Such back-history came to the fore when I taught a course on 'Pakeha Proph- 
ets' that assessed the role of religion in New Zealand cultural nationalism. It became very clear that the notion of the 'holy land' - the land as basis for a new identity, or what can be termed geo-piety - is central to discussions of Pakeha identity.

The study of religion is in many ways an ongoing discussion as to human culture, location and identity - and how these are represented. In this I am proceeding from the position described by Paul Tillich: 'As religion is the substance of culture, so culture is the form of religion' (1967:69-70). Tillich's theology of culture was concerned with disclosing 'the religious meaning of an increasingly secular world' (Schweiker, 2009:138). In working out what this may mean, as a scholar of religion I am partial to the Latin root religare 'to bind together' and therefore to look at religion as the place where discussions as to what binds us together - and conversely separates us - occurs.

We are currently in a time in New Zealand where there are many religious questions being debated - yet crucially they are not seen as such. But if we broaden religion out from the confines of institutional religions and religious practice, the debates over land, over ownership and rights, over one nation or a plurality, over the constructions and debates of identity are all religious questions.

\section{THE CHALLENGE OF KNOWING YOUR IDENTITY}

It was when the local theological version of the wider American-based culture wars - with all their attendant theological and cultural essentialism - broke out in Dunedin in the early 1990s that I came to know Sonny Riini, a chainsmoking, hawk-faced, blunt-speaking Tuhoe Kaumatua. The theological cultural wars were focussed on issues of cultural and contextual theology. Was the gospel inherently settler and European? Could Aotearoa-New Zealand be engaged with not just as place where theology was undertaken, but also as a source for an Antipodean, located, praxis theology? Could theology be enculturated against its dominant North-Atlantic ethos? The location of such debates was telling. Knox Theological College, situated across the road from the Botanic gardens in Opoho, always seemed a strangely dislocated place. Looking backward to its Scots Presbyterian heritage, adjunct a faux-pastiche of an Oxbridge college and yet increasingly riven by debates on church, race, gender, sexuality and culture in New Zealand and feeling, as a perpetual presence, the legacy of Lloyd Geering's 1967 trial for heresy ${ }^{3}$, Knox was fated to be a place of dislocated tensions. 
One day, following yet another seminar in which the collective nouns 'we' and 'you' had been used without reflection, I was walking with Sonny as we attempted to understand why so many seemed threatened by any notion of biculturalism. As we made our way slowly across the car park, Sonny turned to me saying: 'Boy, you know how we hear all this talk about bi-culturalism and identity? Well the trouble is you buggers. We Maori know who we are and so we've got something to say. But you buggers haven't. You Pakeha need to go away and work out who you are and then come and talk with us about biculturalism. We can't tell you who you are and the problem is neither can you.'

Sonny's blunt assessment has stayed with me over the following years. In response, I began re-reading what many now consider passé: the cultural nationalists of the period from the 1930 os to the 1960 . Of course, many literary critics continually mine this area but I wanted to take a look from another angle. As a secular theologian ${ }^{4}$ in the tradition laid down by Tillich, continually mining the intersections of culture and religion, I was looking for the articulation of beliefs that came to define what it means to be Pakeha. There, sitting behind them all was D'Arcy Cresswell, a 'prolific and bad poet', but also an 'eccentric, often brilliant and occasionally profound' (Broughton, 1997:27) prose writer. While described by Patrick Evans as 'a snobbish poetaster-tramp' and 'potty' also - via his influence on Allen Curnow, Charles Brasch and Monte Holcroft - stood 'near the centre of his country's literary culture in his time' (Evans, $2007: 125,126,127)$. In short he is a challenge to our traditional histories of cultural nationalism and identity, being in John Newton's assessment 'a defiantly camp blow against a nationalist house style humourlessly committed to realism, plainness, vernacularism and manly understatement' (Newton, 2003:17).

\section{THE THEORETICAL PATH OF WEAK THOUGHT}

Writing from the position of a secular theologian also necessitates an explanation of the theoretical underpinnings of my project, for to consider Pakeha from such an angle, means an engagement with continental thought given that secular theology is inherently linked to continental philosophy of religion. This theoretical preamble is included because central to my project is the claim that we need to engage with Pakeha as a site of contested belief and a Tillichderived religion-culture nexus.

Therefore reading out of the work of D'Arcy Cresswell, from a position engaged in the current continental debates on religion, I want to institute a counter-narrative taking its starting point from the challenge laid down in the post-foundational thought of Gianni Vattimo. For Vattimo, the death of God 
signals the birth of hermeneutics, for a post-foundationalist world enacts what he terms the age of interpretation. Arising in response to Nietzsche's aphorism 'there are no facts, only interpretations, and of course this too is only an interpretation...' (Vattimo, 1997:6), the age of interpretation is qualified as an age of 'not neutral but engaged knowledge because it is not placed at an ideal place that would claim to be external to the process' (Vattimo, 2002:15). That is, hermeneutics is the expression of knowledge that is necessarily provisional and contested, because the hermeneutic event is not an objective event that we respond to by thought, but rather a transformative event that transforms our existence (Vattimo, 2002:13).

Pakeha, as a condition of modernity, is an act of hermeneutics, a form of participant knowledge that by its very self-expression is a type of engaged knowledge. Claiming to be Pakeha is an act of self-interpretation that transforms the interpreter, for it is giving up the foundational, essentialist claim of New Zealander by engaging in an interpretative strategy - similar to Charles Winquist's positioning of postmodern theology - whereby Pakeha, as an interpretative strategy 'has had to rethink its warrant without authority from outside its own productive formulation' (Winquist 2001:28). Pakeha, as an interpretative strategy is, therefore, like theology, 'a textual production that is always in the middle of existing discourses' that, because it is anti-foundational is a claim without special privilege (Winquist, 2001:28). Pakeha is thus a self-interpretative claim against any claims for either a collective, foundational New Zealand identity or an essentialist European New Zealander identity. However, it also seeks to disestablish foundationalist or essentialist claims that Pakeha is either primarily an expression of birthright or skin-colour. Borrowing from the work of Derrida and Vattimo in Religion (1998), in which they coined the expression 'religionless religion', I wish to argue for the deconstructive positioning of what can be termed 'Pakehaless Pakeha'. Just as religionless religion is an act of interpretation, the slippage between what religion is and yet what religion could or should be, what I term as Pakehaless Pakeha is the interpretative slippage between what Pakeha is - the essentialist and foundational claims - and what Pakeha could or should be. For me, reading out of Vattimo, Pakehaless Pakeha is an expression of the interpretative frame of weak thought, the claim that being is an event that reveals itself through weakening (Vattimo, 1999:39; Vattimo, 2002: 43).

What follows is the beginning of the discussion of the origin of the weak thought of the Pakehaless Pakeha as a condition of modernity; a deconstructive reading making, as Winquist notes, 'all existing texts unsafe' (Winquist, 2001:29). Just as Winquist asks whether perhaps Derrida's religion without 
religion is accompanied by 'a theology without theology' (Winquist, 2001:32)

- that is 'a theology of god who is not being God' (Winquist, 2001:30) (god who is not being foundational) - then by implication, is the hermeneutic of the Pakehaless Pakeha the hermeneutic of Pakeha who are not being Pakeha?

\section{SHORT-CIRCUITING PAKEHA}

It has become somewhat of a literary and cultural cliché for any analysis on New Zealand identity to quote from D'Arcy Cresswell's myth-making memoir of the poet Ursula Bethell, published in Landfall in 1948. Cresswell, as a myriad of selective scholars have told us, proclaimed of Bethell that her poetry was inspired by a particular angle of vision. Specifically, gardening at her home on the Port Hills above Christchurch, earnestly digging, she raised her head and New Zealand was seen for the first time: 'Almost everyone had been blind before' (Cresswell, 1948:283).

As a piece of myth making, this has served the purposes of New Zealand literary scholars very nicely over the past sixty years. New Zealand is the discovery of a suburban, genteel, educated, literary woman and was, in fact, discovered by accident. As always with myths, the reality is somewhat different and more malleable to later interests and orthodoxies. This is not to say that Cresswell dismisses or underplays Bethell's influence. Rather, my concern is with the art of selective quotation. Of course, all quotations are an exercise in selective focus. For the quotation is an interruption of what is presented by inserting another's works and ideas so as to emphasize the point made. Furthermore, the quotation provides a seemingly direct and accessible link to the past because within the quotation, for the general reader, the past speaks authoritatively to the present. The result is that the history of New Zealand identity is a process of selective quotation, compiled in certain ways to suit certain agendas. To claim that my analysis will be otherwise would of course be to raise a false spectre of impartiality and historical omniscience. My use of quotation will be as selective as any other's.

Drawing on Walter Benjamin, Giorgio Agamben expresses the central importance of citation:

Just as through citation a secret meeting takes place between past generations and ours, so too between the writing of the past and present a similar kind of meeting transpires; citations function as go-betweens in this encounter. (Agamben, 2005:139) 
In this interchange of citation occurs Slavoj Zizek's notion of the short-circuit, its 'secret meeting'. A major text and or author is 'short-circuited' by reading via 'a "minor" author, text or conceptual apparatus...If the minor reference is well chosen, such a procedure can lead to insights which completely shatter and undermine our common perceptions' (Zizek, 2003: series foreword). I am interested in what occurs when we approach the history of modern Pakeha as a type of short-circuit reading. To read in a short-circuit manner is to also read via quotation because the quotation acts as both major and minor text according to its use. It is also important, in such a reading strategy, to remember that for Benjamin, 'to quote involves the interruption of its context' (Agamben, 2005:139). This interruption occurs not just as the break in the narrative flow of the original text selectively quoted from, the interruption also occurs in the narrative flow of the text into which the quote is inserted. Therefore, on one level of reading, what occurs in our use of the citation is a type of short-circuit whereby the minor text that is being written is short-circuited through the major text that is deemed worthy of quotation. Of course, this, in turn, sets up the new text as the now-major text to be cited in turn, and so the process continues. However, it is also important to note the way in which citations can themselves become, in isolation, a type of major text for those prepared to quote from the quote and so reflect and enforce the orthodoxies of other scholars. In such practices of quotation cut and paste scholarship, the same quotes appear with startling regularity. It is as if quotations assume not only orthodoxy but also orthopraxis - with each reinforcing the other the more the same sources are continuously mined by scholars.

My discussion on the rise of the idea of Pakeha as a distinctly modern condition makes assiduous use of quotation. This is because, in reference to the sources quoted, this text is indeed a minor text. Compared to my sources, I am a minor author; my primary aim is one of analysing out of past texts rather than creating a singularly new text. In such a move I act as type of cultural forensic scholar, creating a possible outcome through analysis and informed conjecture of scattered source documents. Such forensic scholarship - a type of literary and cultural analysis - is, by its nature, regularly sprinkled throughout by selective quotation from the original sources. Of course, good scholarship involves such activity as a given expectation, yet such is the nature of much paraphrasing that the wider quotation is often radically decontextualised. In turn, bad scholarship quotes from the already quoted, with D'Arcy Cresswell's aphorism a prime example in New Zealand literary and cultural history. Good scholars will, on reading yet another use of Cresswell on Bethell, contextualise the quote for themselves; yet for the wider public, such contextualisation often does not occur. What is quoted is, in effect, isolated as normative and complete 
in itself; for how many readers are going to interrupt their reading, wander off to the closest library containing copies of Landfall and search through the issues until they find the text quoted and then read the surrounding text and indeed the whole article so as to gain the wider perception and understanding? Quotation is therefore a matter of trust; trust by the reader that the author has quoted correctly, and also trust by the writer that not only have they quoted correctly but also that the reader will understand the quoted section as both writers, that is the original writer and then the writer who quotes, intended. Of course the selected quotation, taken as it is in isolation, may be read and reread to prove and enforce; or to emphasize a point either not intended by the original author or, perhaps more often, not regarded as the central substance of their argument. In short, quotation is a short-circuit strategy that helps create new texts and emphases, and yet I would argue quotation is more important than paraphrasing in that the quotation stands the chance of alternative readings in the way a paraphrase does not.

To undertake such forensic scholarship involves, I argue, the necessity of quotation over paraphrase. The difference is that in order to do this I have had to go back to the original writings, read through them and select what I deemed appropriate. Reading to quote rather than reading to paraphrase involves a different type of reading. The aim of paraphrasing is to restate in your own words the ideas of others. In such a process the temptation is to read to confirm what one is seeking to say. Conversely, reading to quote is to be struck by the phrase or insight that demands to be expressed as is to a wider audience. The paraphrase says, in effect, I can express this better than the original; the quote, in contrast, says that what was said has an integrity that cannot be replicated in my attempts to present its essence.

As the Agamben quote states, in the citation the past meets the present, just as in my use of that quote the Italian scholar Agamben, the German Jewish scholar Benjamin and the Pakeha scholar writing this text all meet. In the process, as with the Creswell quote, what has been quoted does not necessarily reflect the wider intention of the original piece. To recognise this as a type of short-circuiting then draws the Slovenian Zizek into the mix as a quotation that will continually reappear as unwritten strategy throughout.

Such a preamble is perhaps a more complex way of saying that this is not the pure impartiality of objective, scientific analysis. Rather, this is subjective quoting of statements selected because I feel they contribute to my overall vision of how Pakeha came to be and what Pakeha means in such an analysis. For, while those who wrote or uttered these words may never have intended 
them to be used in such a fashion, this is, of course, the possibility in all public expressions whether written or spoken. My intention is always to have used such quotations in good faith; and yet the type of selection undertaken can often dramatically change the original emphasis. For what is taken out of the original context is, of course, part of a larger construct and expression. Good scholarship hopefully does not attempt to make present what was not there, by a mischievous use or selection to suit a particular agenda. Effective scholarship, however, may also make clear what was present and yet not noticed either at the original time or, indeed, over later years. Good scholarship also includes the restoring of selected quotations to their original, wider context. Scholars often 'magpie' the work of other scholars: quoting what has already been quoted, referencing what has already been selectively referenced. Cresswell's statement on Ursula Bethell is an excellent example of selective magpieing in that few ever give the impression that they have in fact gone to the original essay in Landfall. Or, if indeed they have, it is with the intention of looking for the specific lines of the quotation and not looking at what surrounds it. For, if we do precisely that and see what surrounds the clichéd quotation, something interesting occurs.

\section{A PEEP FROM THE SUBURBS}

To view the Southern Alps from a Cashmere garden and so discover New Zealand is not the focus of Cresswell's paragraph. His words actually serve as caution to those, following Bethell, who institute their own antipodean version of Psalm 121: 'I to the hills will lift mine eyes, from whence will come mine aid! My help it cometh from the Lord, whom heaven and earth hath made'.

In such an appropriation of the psalmist, the question of the first line is replaced by an exclamation. That is, from wondering where aid will come from to, in the new reading, locating aid in 'the hills'.

Yet if we turn to read Cresswell's statement beyond the limitations of the popular quotation we are challenged by a different way of seeing. For Creswell's quotation runs as follows:

...she was the first to tell the New Zealanders to pull down the blind, to shut out the view, the immensity, the isolation, which Pember Reeves and the others laboured in vain to make explicable and familiar. Pull down the blind on all that, she said, and go back to just peeping out. It was bound to come. It comes from having houses and blinds, just after having whares and shakedowns. New Zealand 
wasn't truly discovered, in fact, until Ursula Bethell, 'very earnestly digging', raised her head to look at the mountains. Almost everyone had been blind before. [italics added] (Cresswell, 1948:283)

We can see how the whole point of Creswell's claim changes when the selective quotation is applied; in this case the section italicised. Cresswell is stressing a turn away from the focus on landscape, a turn away from the pursuit of meaning in a direct encounter with the land and that romantic engagement with the natural world. New Zealand is not to be found by our valiant attempts to make 'the view, the immensity, the isolation' meaningful and explainable in themselves. Instead of standing in romantic awe attempting to deduce location, identity and meaning from the landscape, the meaning of New Zealand is to be discovered in the partial glance as part of everyday activities. The view of 'New Zealand' is actually secondary to both action and locality - that is, the action of New Zealanders in their particular locality. For to purposively search for 'New Zealand' or an essence of 'being a New Zealander' is, in fact, to search for what cannot be seen. The idea of New Zealand being properly seen from houses with blinds, in fact from peeping out from behind the blinds, stands against our mythologies of cultural identity. For the idea that the immense, isolated landscape contains the essence of New Zealand and by implication, New Zealandness sits at the heart of post-colonial dislocation. And yet the importance of Cresswell's observation qua Bethell is that the view is actually best understood from the suburbs.

To look at the landscape and understand what it means to for those who glimpse is to remember that 'to glimpse' occurs from a suburban location and angle of vision. Ursula Bethell was gardening in her hillside suburb and paused. We need to remember that 'Pause' is the name of the poem referred to. While Bethell often ventured into the Canterbury landscape, into the foothills and across the braided rivers, all her perception was, in fact, guided by her suburban pause. The pause is important, for it is an interruption of the everyday task, a shift in focus from the job in hand. What is discovered, that is 'New Zealand', occurs as something perceived when our focus is, in fact, elsewhere. In such events 'the view, the immensity, the distance, the isolation' become understood as part of the everyday, as a backdrop to the everyday activities.

It is interesting to compare Cresswell's claim regarding Bethhell's discovery with Cresswell's own view from the Port Hills. For if we return to the last sentence of his statement, we can see that Cresswell is making a claim for himself here - a claim that he recognises what Bethell saw and how she saw because 
he has seen it also. Note his 'almost everyone'; that should set the question in the reader's mind of 'who else?'

\section{BEING THE FIRST NEW ZEALANDER}

Cresswell's intention is clear, or it is at least clear to those familiar with Cresswell and his various writings, in particular his articles for the Christchurch Press in 1932 that were later incorporated into Present Without Leave (1939), seen as a distinct influence upon Curnow, Brasch and Holcroft and what became known derisively as the South Island myth ${ }^{5}$. Yet I want to go further back, to a letter Cresswell wrote in 1923 wherein he claimed a particular identity for himself that is central to understanding his later statement on Bethell. As one always ready to mythologize time and place (and in this a particular influence on the South Island school), Cresswell makes a claim of personal distinction: 'I am a New Zealander. I endeavour to say it simply, with no challenging idealism. I believe I am the first New Zealander. Someone has to be, and of course that last shall be first' (Cresswell, 1971:28). This comment puts Bethell into context. Her pause is recognized by Cresswell because, as 'first New Zealander', he embodies the New Zealand she sees: a New Zealand, and New Zealander, glimpsed from the suburban garden. Cresswell the first New Zealander is a new type; that is, the New Zealander born here who feels located yet dislocated; a particular type of indigeneity that will come to be expressed as Pakeha.

This indigeneity is different from those in the present day who choose to call themselves 'New Zealanders'. Cresswell's indigeneity is a critical one; effectively a type of cosmopolitan identity that looked both here and abroad for meaning. Cresswell was torn between the land he was born into and the culture he was separated from. The struggle to reconcile the two was, and still is, a major component of Pakeha identity. It is expressed in Jim Traue's Pakeha Whakapapa (1990) whereby the indigenous Pakeha is also connected to a European cultural legacy that struggles to properly locate and acquaint itself here. Something similar happens in another manifesto of Pakeha indigeneity, Charles Brasch's 'Notes' for the inaugural issue of Landfall (March 1947). For Pakeha, being a condition of modernity, is accompanied by those expressions of modernity encompassing angst, doubt, the struggle of the enlightenment and rationality, the search for meaning and location that requires the engagement with the past and yet recognises the need for a new expression and identity in the new context.

For example, Cresswell, arriving by ferry off the Lyttleton heads of Banks Peninsula at daylight, in seeing the Southern Alps 'arrayed in that ancient light 
which the Titans took from Jove' is both delighted and confounded. On the one hand he gazes 'with awe and delight' and yet, there is the qualifier of 'but my heart inquired, "what country is this?" (Cresswell, 1930:153-54). Just prior to this declaration, Cresswell refers to 'England, my spirit's true parent on earth' (Cresswell, 1930:152) and so sets up a tension between spirit and body later echoed by Curnow as the tension of inhabitation and locatedness. In his manifesto of Pakeha identity - otherwise known as the introduction to A Book of New Zealand Verse (1951) - Curnow refers to the Pakeha modernist poetical task as 'a conflict of the exiled spirit' (Curnow, 1951:18) arising (in oft-quoted cliché) out of the awareness of 'the tension between the New Zealander and the land his body inherits but his spirit has not yet won' (Curnow, 1951:26).

\section{PAKEHA AND THE CONDITION OF MODERNITY}

Cresswell and Curnow are important because I wish to argue that, as a condition of modernity, Pakeha is a tension: a tension of indigeneity that recognizes that this here is not all that makes one who one is. The tension is one of body and spirit, of locatedness and dislocation. Just as Cresswell extends classical mythology to the South Island, separating it off from Tikanga Maori, so do later Pakeha of the South Island Myth express Pakeha as inhabitants of an empty land that needs to be articulated through cultural myths of classical and biblical language. To do so is not so much to exclude the presence of Maori (although there is this possibility) but rather to recognize another type of indigeneity - and, most importantly, and this is often overlooked, to actually, paradoxically, also recognise the indigeneity of Tangata Whenua. The postmodern liberal appropriation of Maori myths of origin as now inclusively non-Maori is a form of domestication and assimilation that too often makes such myths and narratives 'New Zealand'; that is, a New Zealand recognised as constituted and expressed by the wishes and interests of the majority settler European culture. It turns culture and mythology into transferable texts devoid of context and history, as acts of cultural phrasing that subsume the minority into the new collective of (European-organised) 'New Zealand'.

The challenge expressed by D'Arcy Cresswell is the challenge of a new, more recent indigeneity that recognises its transferred and shallow roots in this new land, and yet also recognises that being born here does create a sense of belonging, but a sense of belonging continuously in tension with another, older culture and identity. And yet, Pakeha as a modern identity develops down in the South Island precisely because the indigeneity is articulated in what appears an empty land. Cresswell's mythmaking articulates a terra nullis history, a history of a colder and therefore 'barely inhabited' South Island which, in 
turn, means that settlement here has a different basis, not involving a struggle whereby Europeans 'wrested the North Island' from Maori (Cresswell, 1939:7).

What results is the notion of a providential, empty Southern Island that requires its own indigenous mythology supplied by Pakeha: the notion of a new Southern indigeneity that exists alongside the North Island Maori indigeneity. If the North Island is contested and bears the recent scars of intercultural struggle, then the South Island is the land where a new, modern, struggle occurs. If the North Island is a land of struggle with indigenous inhabitants, then the South Island - 'where there was never before to my knowledge, so large and so fair a land to be had for the taking' (Cresswell, 1939:8) - is where a new struggle with nature occurs. In its emptiness, a land without history or landmarks needs to be created anew. The masculine rhetoric of 'taking a large and fair' land waiting without rival suitors needs also to be read back through the biblical tradition of a Promised Land, in this case, without Canaanites (or Maori). Cresswell later makes explicit this mythology of the South Island biblical wilderness. Visiting his friend Cotsford Burdon at Mt. Potts Station near Mt. Summers in the Mid-Canterbury foothills, Cresswell expresses the mythology of the pure interior, imagining 'David and his six hundred hiding from Saul and the Philistines of the plains'. The Canterbury plains, its provincial towns and cities are a 'Dead Sea of Bad business' and the location of a little Sodom of suburban shortcomings by the coast' (Cresswell, 1939:180-81). Yet while Cresswell may use biblical language, seeing the South Island interior as a type of biblical refuge for the chosen outsider, it must also be remembered that he was a professed pagan.

PAKEHA AND LANDSCAPE PAGANISM

Cresswell's paganism is crucial for understanding the Pakeha identity, for a willingness to use biblical language and imagery does not signal an adherence to Christian faith or belief. What it does signal is that which is later expressed by Jim Traue in his Pakeha Whakapapa (1990) - the cultural legacy of Europe, relocated in exile, which becomes the whakapapa, the founding identity and cultural standing point, of Pakeha. Cresswell is free to import European cultural heritage into the South Island because, for him, there is no competing whakapapa, no competing mythology or competing culture down here. This perceived absence - and of course it was only ever a perception out of often deliberate blindness - paradoxically allows the space for a distinctly Pakeha indigeneity to develop that is not Christian but rather post-Christian and pagan. It is, in the worlds of Jason Stanley, what can be termed for Pakeha as 'Landscape paganism' ${ }^{3}$; a paganism that is aesthetic and arises out of a way of 
seeing (or glimpsing) rather than from environmentalism or animism. The South Island can also become the antipodes, not so much to Britain, but rather, recognising its latitude, to the Mediterranean. Cresswell, recounting a boat trip within the grandeur of Lyttleton Harbour, mythologises the experience: 'I felt immortal that morning. The sea there is turquoise, not blue, and the hills there as bright terra-cotta, tipped with caverns and crags. The sun here has a Mediterranean brightness and heat' (Cresswell, 1971: 65).

In a similar manner to American and British aesthetes and writers fleeing the constrictions of their home societies by venturing to the sun-lit, pagan, mythological Mediterranean, here in the antipodes, Cresswell, himself the epitome of the Pakeha aesthete, suggests that a similar, if temporary, release and freedom can be gained in the heat and colour of the barren South Island. This turn to the natural world as the source of meaning is as Creswell wrote 'the anciently native' and increasingly centralised for him 'about nature'. It is this that forced his reassessment of a colonial society that, being 'newly transplanted', was his 'first love' (Cresswell, 1971:69-70). Yet the discovery of ancient nature in turn forces a type of exile within an indigeneity that exists outside of 'the social entity', an exile into 'a wild and half-supernatural ordination' whereby Cresswell perceives himself 'to be the only inhabitant' (Cresswell, 1939:179). As this only inhabitant, Cresswell is again expressing a type of indigeneity; in the terra nullius he is the first inhabitant, the first perhaps to see, to perceive, to experience New Zealand as it 'truly is'. This is the claim that stretches back to Cresswell's statement about being the first inhabitant, and will be repeated in more elliptical form in his memoir of Ursula Bethell.

The true inhabitant also either looks across the city to the hills, or turns their back on the city and looks to the interior. The Pakeha as mythologized by Cresswell, and as followed by other Pakeha mythologists, rejects what is described as variously the appalling materialistic standard of life... [whereby] ... the one crime is not to get on and make money' or an urban society of 'a fast, uncultured sort' (Cresswell, 1971:64).

The tension Cresswell expresses is that the truth of the modern world for New Zealand is either to be found overseas in the ancient European culture or to be found here in the encounter with the empty land. The rejection of materialistic New Zealand urban society is a founding part of the South Island Myth and sits at the centre of the Pakeha identity; an uneasy tension now most expressed in suburbia. This tension occurs in Cresswell as he comes to perceive the reality of his native land separate from any romantic perceptions. In the late 1920 s he could write confidently concerning the restorative nature of New Zealand 
upon his health, with 'the traditions, customs and scenery of my native land' (Cresswell, 1930:12) acting as the foundation of his poetry. Yet by 1932 a change occurs; nature becomes the focus for meaning while 'colonial humanity and its aspirations' has been found 'shallow, hostile and fruitless' (Cresswell, 1971:70). Of course, this turn to nature as the essentialist, restorative force for 'the first New Zealander' is yet another expression of the Romanticist legacy. Yet it can also be seen as a type of post-colonial statement in claiming an indigeneity separate from those who still exist as 'colonial humanity'; for to exist in an orientation separate from the suburban colonial society is to claim an identity that seeks a reference into what is not colonial.

A MODERN POST-COLONIAL INDIGENEITY OF EXILE

This Pakeha indigeneity of course cannot pre-date the colonial period, but can exist as counter-narrative to it; an indigeneity of repudiation that no longer sees itself created or constrained by colonial realities. This indigeneity as postcolonial modern, the indigeneity of the post-colonial 'just now' (from the Latin modos), also expresses itself in that most central of modernist tropes, the exile. What makes the modernist exile in the South Island so fascinating is that it is not so much an exile as New Zealander from the world centres in the Northern Hemisphere; rather, it is an exile within the continuing colonial realities, seeking a re-location as indigenous within the empty southern land. The task of the newly indigenous is to create meaning in what Charles Brasch termed 'The Silent Land', a society where:

The plains are nameless and the cities cry for meaning, the unproved heart still seeks a vein of speech.

(Brasch, 1951:133)

Of course for the colonial, the plains are not nameless (they are the Canterbury plains) and the cities, by their existence, are a statement of meaning in themselves while 'the vein of speech' is speaking as a New Zealander. Yet the newly emergent modern indigeneity of Pakeha can accept all this but still find itself in exile precisely because it is no longer colonial. Here the distinction between 'New Zealander' and 'Pakeha' needs to be noted because it is too easy to conflate the two. For example, Lydia Wevers claimed "Pakeha", with its connotations of a chosen indigeneity, is the hegemonic term of "New Zealander" (Wevers, 2004:110). Wever's understandable critique is of those who wish to claim a universalistic indigeneity that seeks to neuter Maori claims of Tangata Whenua. She reminds us that such a reductionist approach actually fails to stand up, either historically or in contemporary culture. Historically, Pakeha 
is the identity that can be attached to a particular type of expression of being a New Zealander, but of being a type of New Zealander that transcends being a European New Zealander. Conversely, in contemporary usage, Pakeha is only really used as a hegemonic term by those seeking to implement a particular type of bi-cultural agenda that takes all European New Zealanders as a collective identity that can be reappropriated under the emergence of bicultural treaty language over the past twenty years. This becomes the language of the Crown in political statements and rulings wherein the terms Maori and Pakeha become collective nouns without nuance in the service of the state. In effect, tying Pakeha to a hegemonic New Zealand identity is to continue the colonial context into the present day. It is also to deny the central importance of regionalism as discussed by Gregory O'Brien at the same conference where Wevers made her statement.

\section{RETHINKING REGIONALISM}

O'Brien's nuanced assessment seeks a way out of nationalist assumptions, agendas and labels and proposes the case of 'misrepresented regionalists' (O'Brien, 2004:35). Re-reading the New Zealand Pakeha quest for identity through a European lens (and in this perhaps an unconscious echoing in particular of Charles Brasch's first Landfall 'Notes' of 1947), O’Brien positions regionalism as 'more a recognition of divergence and chaos, dialects and difference' over and against nationalism's 'call to order' (O'Brien, 2004:36). I wish to extend and rework O'Brien's regionalism and state that what has been perceived - and latterly more often dismissed as the South Island Myth - was in actual practice a particular experience of East Coast, South Island regionalism that became instituted as the basis for de-facto Pakeha nationalism. This regionalism begins with the first Pakeha regionalist of the East Coast, D'Arcy Cresswell, as the first modern precisely because he situates himself as anti-modern. That is, Cresswell locates himself as against the particular 'just now' of the late colonial society in a manner that partakes of a specific regionalism over and against the local expressions of an emergent nationalism.

In 1960, Charles Brash described Cresswell in terms that can be seen to locate him as antimodern; that is as antimodern in defiance of the emergent modern New Zealand. Cresswell, according to Brasch, was what could be termed, in both cultural and sexual terms, the inverse New Zealander, an 'eloquent contradiction of everything New Zealand then put its faith in, the New Zealander in reverse' (Brasch, 1960:117). Cresswell was, therefore, the antimodern modern, the regionalist nationalist, the one who positions a new identity that creates a new, regional voice over and against any claim of a national coherence. 
The antimodern repositioning of Cresswell occurs because, as Arthur Versluis has argued, 'antimodernism is fundamental to the creative impulse in modernity'. Furthermore, 'modern industrial society in its very nature calls forth antimodernism in the creative individual' (Versluis, 2006: 96). Cresswell's antimodernist stance, expressed in his celebration of the regional identity and a specific regional identity at that - is also situated in opposition to the towns and cities of the plains, the locations of industry and modern life. His claim to be the 'first New Zealander' is, in its paradoxical identity, the basis of an antimodern regionalism precisely because as O'Brien later parenthetically muses: '(Maybe a nation is a fiction but a region is a non-fiction - a fact?)' (O'Brien, 2004: 45). Cresswell had returned home to New Zealand in search of a nation, in order to discover his nation - but the more he searched the less he found palatable and meaningful. Yet at the same time, in his writings he expresses a growing rediscovery of the regionalist identity, an identity that enables him to not only claim to see New Zealand (as Ursula Bethell would likewise) but also enable him to claim the proto-Pakeha identity of being the 'first New Zealander' precisely because he has seen through the pretence of the nationalist claim. The New Zealander is, pace Cresswell, first and foremost the creative regionalist, the antimodernist, because they are opposed to the order of nationalism. As O'Brien, eighty years on, echoes, regionalism involves 'a realisation that nationalism is at its most palatable when its country does not exist' (O'Brien, 2004:46). O'Brien's 'epiphanous moment' occurs when he is in the Catalan nation of southern France and northern Spain. Conversely, for Cresswell, his epiphanous moment occurs when he returns to his home country and finds the nation he sought sadly lacking. As Toss Woolaston wrote to Rodney Kennedy upon meeting Cresswell at Ursula Bethell's house in 1933, and in particular in reference to Cresswell's Poet's Progress: 'So amazingly detached and critical about New Zealand it reads like the diary of an early discoverer, supposing such had discovered us as we are now' (Trevelyan, 2004:24).

What Cresswell claims to discover is the antimodern disruption: 'that there are two "countries" here', one being 'the native and all its physical forms, which abide, as mountains and rivers', and in opposition - and rejected by Cresswell'the European imported society' (Cresswell, 1971:73). Against this must be reread his claim of being the 'first New Zealander'; that can now be seen to be the first to be able to relocate an identity from the 'European imported society' to being part of 'the native and its physical forms'. The 'first New Zealander' is the one who, as with Bethell, is able to see the 'native and physical forms' as that which frames the borders of their native land. Such relocation is to be truly regionalist, and to be of the region first and foremost as indigenous identity involves the antimodern rejection of the unifying demand of 'the European 
imported society.' For to be the 'first New Zealander' is to reject being one with 'the European imported society'; it is, as Brasch noted, to be the New Zealander in reverse, just as today, to be Pakeha is likewise to situate oneself in a reversal from the hegemonic modernist unitary claim of New Zealander.

Frank Sargeson, a fellow dissenter, stressed the central importance of Cresswell's Ur-regionalism in the articulation of the new Pakeha indigeneity. Noting Cresswell's 'New Zealand' was primarily an expression and experience of Canterbury that stretched to the banks of the Waitaki River, Sargeson recognised the central truth of such a regionalist identity because he 'was forever bound to the hilly stump farms of the King Country, balloted-for areas of third-class land' (Sargeson, 1960:350). Yet precisely because they were so regionalist in their foundational identity, both could articulate a new type of critical indigeneity that was the regionalist voice, as both land and critic, within and yet against any attempt to impose a collective nationalist identity or voice. This paper is therefore arguing for a rethought possibility of first seeking to engage with Pakeha as a series of regional representations, claims and identities, positioning Pakeha as a counter-national voice and identity. Thus Pakeha is a regionalist identity involving being within, yet against; in critique, and often in rejection of; the national and nationalist demand to be a New Zealander. Of course not all European New Zealanders are necessarily Pakeha, nor will they wish to be. For Pakeha is first and foremost a type of belief, a specific angle of vision: a regional pause. Perhaps, in reply to Sonny, we can begin to know who we are from that particular, regional bugger Cresswell.

\section{NOTES}

1 The use of 'bugger' in this essay is deliberately two-fold. While Cresswell is, in his homosexuality, 'a bugger', over the past twenty years the term 'bugger' as a catch-all noun (both affectionate and dismissive - and sometimes both ance - as with Sonny Riini's usage) and as expressive exclamation has entered the mainstream colloquial New Zealand lexicon. This occurred primarily via a series of highly popular television advertisements for the Toyota Hilux. The power and strength of the Hilux caused rural people (and dogs!) to exclaim 'bugger.' Bugger' has therefore lost its specificity and its offence in its colloquial use in New Zealand.

2 I wish to thank my anonymous reviewers for their very helpful feedback and critique. 
3 In 1967 Lloyd Geering, Principal of Knox Theological Hall, was publicly tried by the General Assembly of the Presbyterian Church for Heresy (Doctrinal Error). Geering was acquitted and went on to be a leading New Zealand public intellectual in the field of Religious Studies. See Lloyd Geering, Wrestling with God, Wellington, Bridget Williams Books, 2006.

4 Perhaps best described as a secular theologian and critical theorist, my teaching and research focus on religion as hermeneutics; that is as 'the necessary problem' in the project of modernity and the associated issues of location, identity and secularity. Put simply, my approach starts from a view of religion as 'the claim of an alternative' that takes various forms and expressions, including culture, society and politics. Secular theology is best understood as the critical thinking on any claim to value and meaning in the saeculum - and perhaps most centrally, against 'religion' itself.

5 See in particular the discussions on Cresswell by Curnow (and Peter Simpson) in Allen Curnow, Look Back Harder. Critical Writings 1935-1984, Peter Simpson (ed), Auckland: Auckland University Press 1987; Lawrence Jones, Picking Up the Traces: The Making of a New Zealand Literary Culture 1932-1945, Wellington: Victoria University Press, 2003; John Newton, 'Poetry and Other Marvels: D'Arcy Cresswell on His Own Terms', Journal of New Zealand Literature 21 (2003), pp. 14-31; William Broughton, 'Curnow's Anthologies and the Strange Case of Walter D’Arcy Cresswell', Journal of New Zealand Literature 15 (1997) pp. 26-39.

6 Jason Stanley in conversation with the author, July 2005.

\section{REFERENCES}

Agamben, G. 2005 The Time That Remains. A Commentary on the Letter to the Romans, Stanford: Stanford University Press.

Brasch, C. 1951 'The Silent Land' in A. Curnow (ed) A Book of New Zealand Verse 1923-50, Christchurch: Caxton Press [revised edition]:133.

Brasch, C. 1960 'Notes' Landfall 54, vol.14, no.2, (June):117.

Broughton, W. 1997 'Curnow's Anthologies and the Strange Case of Walter D’Arcy Cresswell', Journal of New Zealand Literature, 15:26-39.

Cresswell, W.D. 1930 The Poet's Progress, London: Faber \& Faber Ltd. 
Cresswell, W.D. 1939 Present Without Leave, London: Cassell \& Company Ltd.

Cresswell, W.D. 1948 'Ursula Bethell: Some Personal Memories', Landfall 8, (December):275-96.

Cresswell, W.D. 1971 The Letters of D'Arcy Cresswell. Selected by H. Shaw. Christchurch: The University of Canterbury, The Caxton Press.

Curnow, A. (ed) 1951 A Book of New Zealand Verse 1923-50. Christchurch: Caxton Press [revised edition].

Derrida, J. and Vattimo, G. (eds.) 1998 Religion, Cambridge, UK: Polity Press.

Dowling, B. 1949 Canterbury and other Poems, Christchurch: The Caxton Press.

Evans, P. 2007 The Long Forgetting. Christchurch: Canterbury University Press.

Glover, D. 1945 The Wind and the Soul. Christchurch: The Caxton Press.

Jones, L. 2003 Picking Up the Traces: The Making of a New Zealand Literary Culture 1932-1945, Wellington: Victoria University Press.

Newton, J. 2003 'Poetry and Other Marvels: D'Arcy Cresswell on His Own Terms' Journal of New Zealand Literature, 21:14-31.

O'Brien, G. 2004 'Creative New Zealand?' in M. Williams (ed), Writing At The Edge Of The Universe, Christchurch: Canterbury University Press:33-48.

Sargeson, F. 196o In 'D’Arcy Cresswell, by his Friends', Landfall 56, vol.14, no.4 (December):350.

Schweiker, W. 2009 'Theology of culture and its future' in R. Manning (ed), The Cambridge Companion to Paul Tillich, Cambridge: Cambridge University Press:138-151.

Shadbolt, M. 1993 One of Ben's, Auckland: David Ling.

Simpson, P. (ed), 1987 Allen Curnow, Look Back Harder. Critical Writings 19351984, Auckland: Auckland University Press.

Traue, J.E. 1990 Ancestors of the Mind. A Pakeha Whakapapa, Wellington: Gond- 
wanaland Press.

Tillich, P. 1967 On The Boundary, London: Collins.

Trevelyan, J. (ed) 2004. Toss Woollaston. A Life in Letters, Wellington: Te Papa Press.

Vattimo, G. 1997 Beyond Interpretation, the meaning of hermeneutics for philosophy, Cambridge: Polity Press.

Vattimo, G. 1999 Belief, Stanford, Calif.: Stanford University Press.

Vattimo, G. 2002 After Christianity. New York: Columbia University Press.

Versluis, A. 2006 'Antimodernism', TELOS 137, (Winter): 96-130.

Wevers, L. 2004 'The Politics of Culture', in M. Williams (ed) Writing At The Edge Of The Universe, Christchurch: Canterbury University Press:109-122.

Winquist, C.E. 2001 'Postmodern Secular Theology' in C. Crockett (ed.) Secular Theology. American Radical Theological Thought, London and New York: Routledge: $26-36$.

Zizek, S. 2003 The Puppet and the Dwarf: The perverse core of Christianity, Cambridge, Mass.: The Miт Press. 